\title{
CURRENT STATUS AND PROSPECTS FOR ORGANIC AGRICULTURE IN POLAND
}

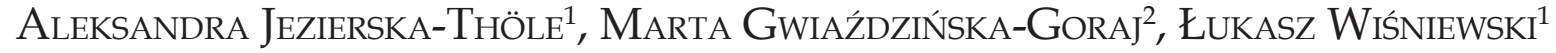 \\ ${ }^{1}$ Nicolaus Copernicus University, Faculty of Earth Sciences, Department of Spatial Management and Tourism, \\ Torun, Poland \\ ${ }^{2}$ University of Warmia-Mazuria, Department of Planning and Spatial Engineering, Olsztyn, Poland
}

Manuscript received: January 4, 2017

Revised version: March 13, 2017

JeziersKa-Thöle A., GwiaździńSKa-Goraj M, WiśniewSKi Ł., 2017. Current status and prospects for organic agriculture in Poland. Quaestiones Geographicae 36(2), Bogucki Wydawnictwo Naukowe, Poznań, pp. 23-36, 2 tables, 13 figs.

AвSTRACT: Organic farming is part of a sustainable development model; at the same time it is becoming a prerequisite for the multifunctional development of rural areas. The main aim of this study is to identify the state and analyse changes in the development of organic agriculture in Poland as well as to present the possibilities for its development. The time horizon of the study covers the years 2003 to 2015. The basis of the research was an analysis of the literature, the Report of the Chief Inspectorate of Trade Quality of Agriculture and Food (IJHARS), and national empirical research; it also includes an analysis of the results of surveys carried out on organic farms in the summer of 2016, as well as our own observations. The study showed that in the years 2003-2015 Poland saw a rapid increase in the number and area of organic farms due in part to the introduction of EU subsidies. Spatial analysis of the proportions of farms by voivodeship shows that in 2015 most were recorded in Warmia-Mazuria, Podlasie and West Pomerania. Similar to the increase in the number of organic farms, the years 2003-2015 saw an increased area of organic farmland. Poland is second in the world in terms of growth in the area of organic farms. In the years 2003-2014 the average size of an organic farm remained at about 25 ha and was higher than the average size of conventional farms (10 ha). In 2014 the crop structure was dominated by fodder plants $(35.8 \%)$, and meadows and pastures $(31.5 \%)$. In terms of livestock production, cattle and horses had the biggest share.

KEY WORDS: organic farms, agriculture, Poland

Corresponding author: Aleksandra Jezierska-Thöle, Department of Spatial Management and Tourism, Faculty of Earth Sciences, Nicolaus Copernicus University, ul. Lwowska 1,87-100 Toruń, Poland; e-mail: alekjez@umk.pl

\section{Introduction}

The development of organic agriculture in Poland and other European Union countries is a consequence of ongoing transformations in the economic and social spheres, and especially in the agro-food complex. The agricultural policy of the EU in the second half of the $20^{\text {th }}$ century was mainly based on instruments stimulating growth in production to ensure food self-sufficiency. The effect of those changes was the specialisation and technical intensification of production as well as the degradation of the agricultural and natural environments (Zysnarska 1997). Such features as multidirectional production, self-sufficiency and the organic character of farms lost importance. The increase in the consumption of artificial fertilisers and pesticides became one of the determinants of environmental degradation.

The negative effects of intensive agriculture made it necessary to change the approach to its environmental impact. Consumers started showing 
an interest in organic food produced without the use of chemicals. Changes in consumption patterns were also the effect of health risks caused by environmental pollution, lowering the quality of food products (Hamm, Gronefeld 2004).

In the $21^{\text {st }}$ century, the role of agriculture in the economy is changing and it is transforming itself towards sustainability. Organic agriculture, which is a sustainable system in ecological, economic and social terms at the national, regional and local scales, has started playing an important role. It is a modern method of farming which enables sustainable soil fertility, animal health and the biological quality of crops. Currently, organic agriculture is one of the fastest growing branches globally, and the trend is particularly evident in the EU countries (Kołodziejczak 2015). In Western Europe intensive development of organic agriculture began in the 1980s, while Poland has witnessed dynamic growth in the number of organic farms since 2002. The development of organic agriculture has been the outcome of negative factors, such as groundwater and surface water pollution by nitrogen compounds, reduction in the profitability due to overproduction of conventional foods, as well as a reduction in confidence in the food produced by intensive methods, including the fear of BSE and GMOs (Christian 2008).

The main aim of this study is to identify the state and analyse changes in the development of organic agriculture in Poland as well as present the possibilities of its development. An important part of the study is showing the importance of organic agriculture in local development.

\section{Materials and methods}

The time horizon of the study covers the years 2003 to 2015. This is the period between two censuses in agriculture. It includes the preparation stage of Polish agriculture before the country's accession to the European Union, i.e. the adaptation of the national agricultural policy to the standards and requirements of the EU (acquis communautaire), and the implementation of pre-accession aid programmes. The period since 2004 involved the start-up and implementation of the tools of the Common Agricultural Policy. The basis of the research was an analysis of the literature, the Report of the Chief Inspectorate of Trade Quality of Agriculture and Food (IJHARS), and national empirical research; it also includes an analysis of the results of surveys carried out on organic farms in the summer of 2016, as well as our own observations.

The basic administrative unit adopted for analysis was the voivodeship due to the lack of current data from the study period at a lower administrative level. The data referring to the whole of Poland were given in relation to other EU countries.

The work includes the following research stages:

1. Presenting the development of organic farms in Poland and in Europe on the basis of specialist literature.

2. Underlining the importance and function of organic farms from the economic, social and environmental points of view on the basis of the literature and field research.

3. Determining the state as well as the nature and pace of change in the development of organic farms in Poland.

4. Presenting organic producers by categories of business.

To evaluate the development of organic farming the following groups of characteristics were adopted:

1. Organisational and production features expressing the number and area of organic farms by individual size groups.

2. Production features - expressing the potential of plant and animal production.

In order to fully present the spatial changes, a graphical method was used in the form of cartograms (presenting the average intensity of a phenomenon in voivodeships), as well as choropleth maps and charts.

\section{The beginnings of organic agriculture in Poland and Europe}

The beginning of organic agriculture is seen in the concept of biodynamic agriculture developed by Rudolf Steiner, Austrian philosopher and naturalist, creator of a philosophical-religious system called anthroposophy. The interpretation of nature resulting from anthroposophy emphasises a close interdependence of the 
Earth, Man and the Cosmos, and assumes that by certain preparations and actions Man can activate the various forms of energy present in nature (Koepf, Plato 2001). In Germany, the populariser of anthroposophy-based agriculture was E. Bartsch, who in the 1920s led the National Association of Biodynamic Agriculture and oversaw the publishing of Demeter-Monatsschrift on biodynamic agriculture (Vogt 2000). The biodynamic method involves the use of biodynamic substances (e.g. silica for plants) and herbal remedies (e.g. chamomile or nettle) in the compost. Another method of organic production in the organic-biological method (organisch-biologischer Landbau) was developed in the 1930s and 1940s by Hans Müller, a Swiss politician, and Hans Peter Rusch, a physician and microbiologist from Germany. The organic-biological method helps obtain optimal high-quality yields without the use of mineral fertilisers and pesticides, but by paying particular attention to the succession of crops in rotation and the use of green manure, including catch crops protecting the soil in winter and maintaining soil fertility, in the conditions of nutrient circulation. The agrotechnical foundation of this method (most carefully developed in harmony with nature, as compared with other directions of agricultural production) became the basis of agricultural technology in organic agriculture (Stankiewicz 2001). Another conception of organic agriculture was developed in the 1940s in England and the countries of the British Commonwealth by A. Howard and E. Balfour. In this method, a special role is attributed to organic matter and mineral substances (by the addition of minerals of natural origin), as well as studying and using the relationship between soil and plants. Organic agriculture was developed in the United States by F. Sykes, J.I. Rodale and R. Rodale. At the turn of the 1960s biological agriculture (l'agriculture biologique) was developed in France by R. Lemaire and J. Boucher. In this method, high importance is attributed to improving soil fertility through seaweed fertilisers (Sołtysiak 1993).

The first organic farm in Poland appeared in the 1930s. Stanisław Karłowski, senator of the Second Republic, introduced biodynamic land cultivation on his estate in Szelejewo near Gostyń (Jezierska-Thöle, Biczkowski 2013). After World War II, Julian Osetek in 1960 continued research into organic-biodynamic agriculture. However, in the socialist period, organic agriculture did not matter much to the national economy. Only in 1986-87 did a pioneering group of farmers start to reorganise their farms towards organic production. In the 1990s, during the transition period, organic agriculture again attracted the interest of farmers, consumers and the government. In 1989 Mieczysław Babalski of Pokrzydowo (Kujavia-Pomerania) and other farmers initiated the first Association of Ecologically Produced Food EKOLAND based in Przysiek near Torun; in 1990 the Association awarded certificates to 27 farms. Another organisation which has held attestation rights since 1993 is the Polish Society of Organic Agriculture. The first draft of the law on organic agriculture was established by the Minister of Agriculture and Food Economy in 1997, and the Workgroup on Organic Agriculture was set up. The Ministry of Agriculture sent the first subsidies to organic farmers to compensate for farm inspection costs, and since 2000 such farms have been covered by subsidies per hectare of crops. Since 2004, organic farmers and those converting to organic agriculture can participate in the Agri-Environmental Scheme. In 2015, the socalled "ecological action" began and both forms of support allow farmers to apply for subsidies for organic production.

Organic agriculture is currently one of the fastest growing agricultural sectors in the world, particularly in the European Union. The recent years show a constant growth in both the area and the number of organic farms (The World ... 2010). In the years 1999-2013 the area of ecological farmland in Europe grew by an average of about 500,000 ha a year. The development of the organic agriculture sector is also reflected in the number of processing plants, as well as the range of organic products available on the market (Runowski 2009). In 2013 in Europe there were 11.5 million ha of farmland where production took place organically. European countries with the largest area of organic farmland were Spain (1.6 million ha), Italy (1.3 million ha), and Germany and France (1.1 million ha each, The World ... 2010). Countries with over 10\% of the land taken by organic farmland include Lichtenstein (31\%), Austria (19.5\%), and Sweden (16.3\%, The World ... 2010). 


\section{Importance and function of organic agriculture}

The term "organic agriculture" has been recognised in the legislation of the European Union as a synonym for much older terms, such as biodynamic agriculture (Koepf, Plato 2001), organic agriculture (Vogt 2000), and biological agriculture (Pradziadowicz 2013), i.e. terms derived from the historical names of agricultural production methods from which the principles of organic agriculture were derived. In the Polish literature there are several other terms used to name this form of farming, e.g. alternative, bio-organic (Kuś 2002), unconventional (Granstedt, Tyburski 2006), and biodynamic (Grykień 2005).

Organic agriculture is defined as a system of farming based on balanced plant and animal production with the use of biological and untreated mineral materials. It is a permanent, self-sustaining and economically secure system. Organic production combines environmentally-friendly farming practices, promotes high biodiversity, and ensures proper animal welfare. The basis for the functioning of organic farms is the elimination of chemical technology (fertilisers, pesticides and others) from agricultural production (Kozłowska 1999). Organic agriculture is a modern system of agricultural production, based on the experience of many generations along with the latest achievements of science. This production is more difficult and labour-intensive, and it requires an in-depth knowledge of the mechanisms occurring in nature. Yields are often smaller, but the quality and content of vitamins and nutrients in the obtained products leads to market success today (Stachowicz 2008). Organic agriculture requires many improvements and innovative solutions, a prerequisite for ensuring conditions of agricultural production in accordance with the requirements (Tabo, Szczuka 2012).

The aim of organic agriculture is to maintain a balance between resources and the requirements of the economy (Stawicka et al. 2004). Organic agriculture matches the concept of sustainable development and offers numerous benefits for the environment and society (Pearce, Turner 1990). The sustainable development of agriculture and rural areas is an integral part of the overall concept of sustainable development. In Poland this development has been implemented since 2004, i.e. when the National Development Plan for Poland as well as the Accession Treaty and Development Strategy for Poland were signed. The most important of these documents are shown in Table 1.

Table 1. Advantages of organic farming.

\begin{tabular}{|c|l|}
\hline Function & \multicolumn{1}{c|}{ Types of activity } \\
\hline Production & $\begin{array}{l}\text { - crop and livestock production } \\
\text { - recycling of waste and by-products of plant and animal origin as a means of plant and animal pro- } \\
\text { duction } \\
\text { - production of biomass for renewable energy }\end{array}$ \\
\hline Economic & - processing of healthy food; agriculture, forestry, transport, tourism, environment \\
\hline Social & $\begin{array}{l}\text { - prevents excessive migration of rural population } \\
\text { - allows keeping workplaces in rural areas }\end{array}$ \\
\hline Cultural & $\begin{array}{l}\text { - preserves diversified agricultural landscape } \\
\text { - follows the rules of environmental ethics }\end{array}$ \\
\hline Ecological & $\begin{array}{l}\text { - nature protection; protection of animal welfare } \\
\text { - increases soil fertility } \\
\text { - it is devastating to the environment in a minimal degree }\end{array}$ \\
\hline Services & $\begin{array}{l}\text { - agricultural and forestry services } \\
\text { - workplace for rural population } \\
\text { - balance between nature and economic and social spheres }\end{array}$ \\
\hline Health & $\begin{array}{l}\text { - resignation from synthetic pesticides in favour of alternative methods of crop protection } \\
\text { - provides high nutritional value of products } \\
\text { - provides products of high health quality }\end{array}$ \\
\hline Ethical and & - preserves diversified rural landscape \\
aesthetic & - follows the rules of environmental ethics \\
\hline
\end{tabular}

Source: own development based on Łuczka-Bakuła (1997), Rogall (2010), Hirschfeld et al. (2009), Jezierska-Thöle et al. (2016). 


\section{Changes in the agrarian structure of organic farms in Poland}

According to the data of the Chief Inspectorate of Trade Quality of Agricultural and Food Produce (IJHAR), since the early 1990s interest in organic production has been growing. In 1990, there were 27 organic farms registered (including both certified and those under conversion). In subsequent years we have seen a slow but steady increase in the number of such farms. In the pre-accession year of 2003, there were 2,286 organic farms in Poland, and 10 years later, after Poland's accession to the EU, this figure grew to 26,598 (Fig. 1).
From 1990 to 2003 there was a slow but steady increase in the number of organic farms; after 2003 there was a sharp increase due in part to the introduction of EU subsidies and the introduction of the EU regulations on organic agriculture. The Common Agricultural Policy allowed substantial financial support for organic agriculture in the framework of the Environmental Management Scheme, which is one of the elements of the Rural Development Plan (RDP).

The increase in the number of farms from 2003 to 2013 is linear, as illustrated by the trend line shown in Fig. 2. The equation for the straight line trend of the number of organic farms in this period took the form of $y=2,099 x+1,455$. This means that the number of farms increased by an average

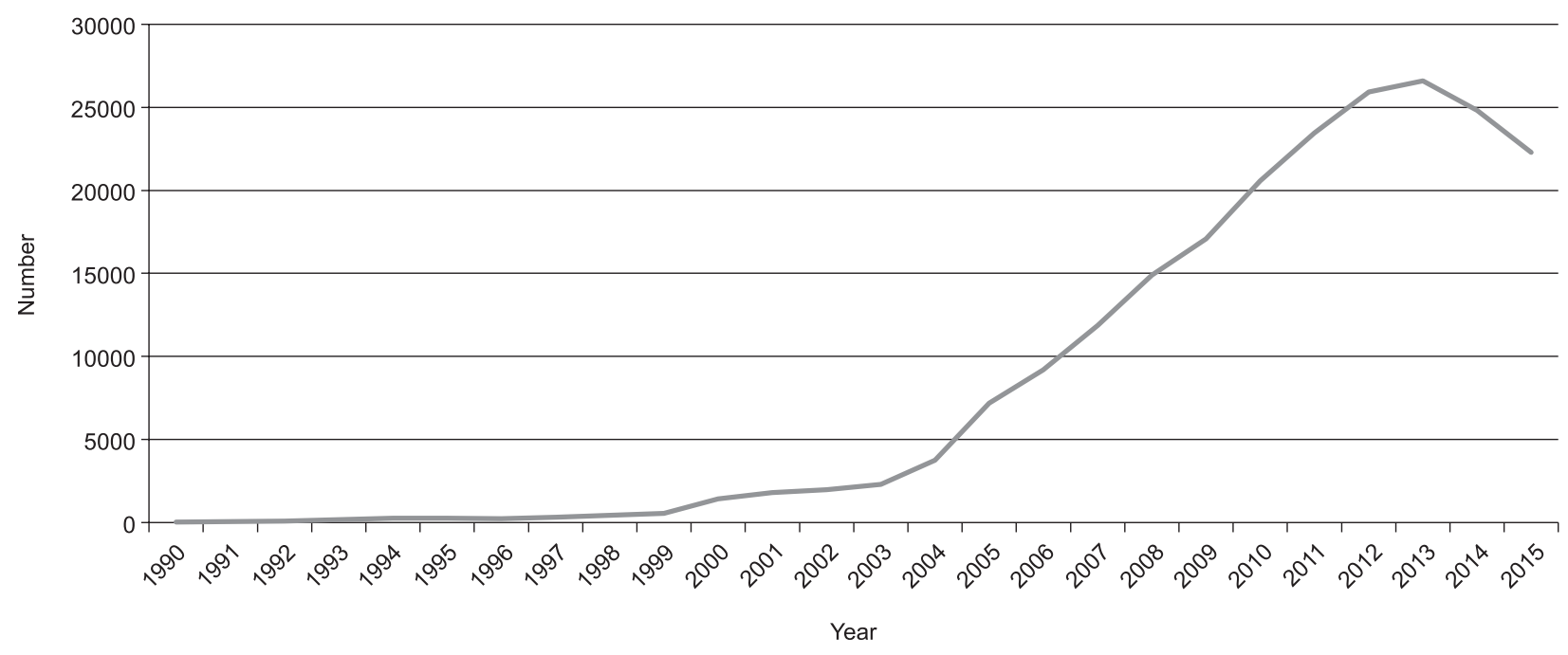

Fig. 1. Number of organic farms in Poland in 1990-2015.

Source: own calculations based on the IJHARS report.

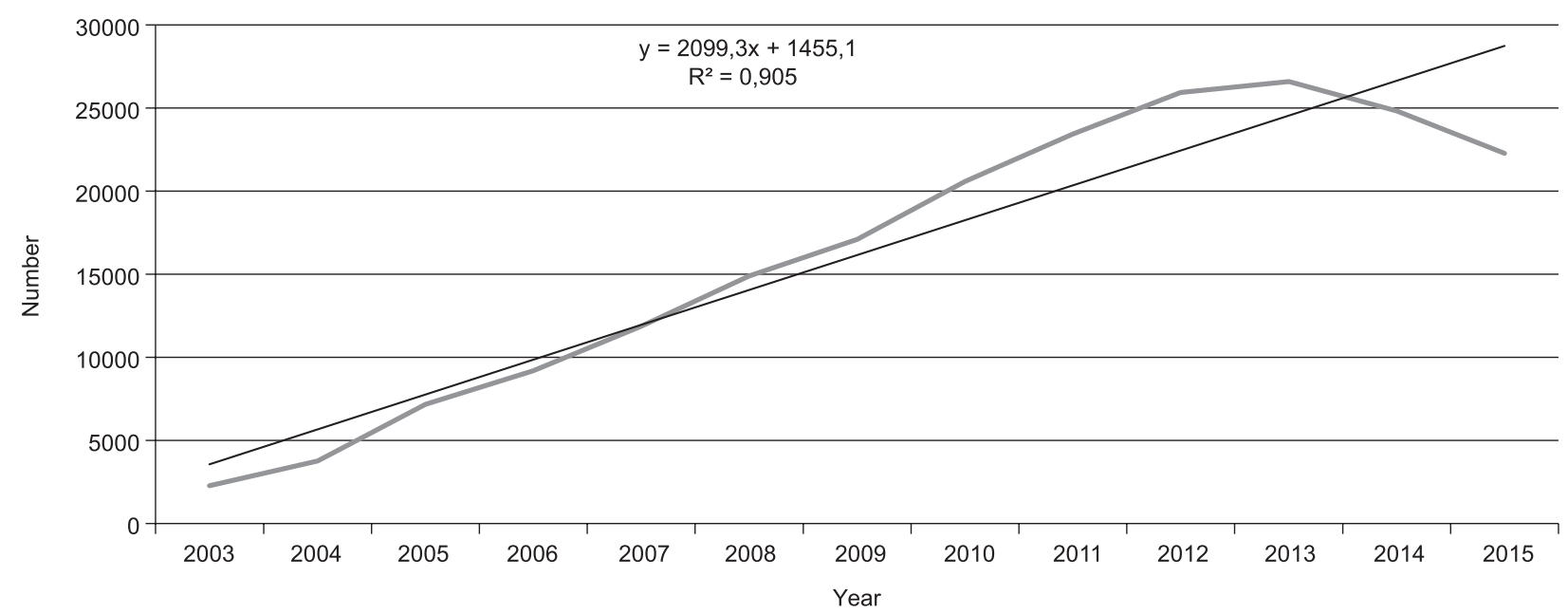

Fig. 2. Number of organic farms in Poland by voivodeship in 2003-2015. Source: own calculations based on the IJHARS report. 


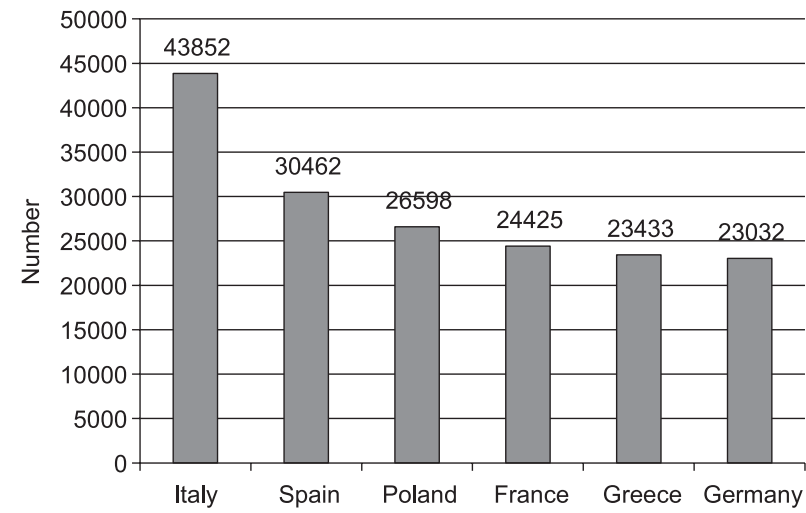

Fig. 3. Number of organic farms in selected EU states in 2014.

Source: own calculations based on The World of Organic Agricultural Statistics and Emerging Trends, 2010.

of 2,099 entities annually. $90 \%$ of the equation of the straight line trend is explained by a matching regression line $\left(R^{2}=0.905\right)$. The largest increase in the number of organic farms, compared with the previous year, was recorded in 2013 , by 26,598 farms. In 2013 there was a downward turn.

Compared with other EU countries, Poland took third place in terms of the number of organic farms, after Italy and Spain (Fig. 3). Just behind Poland were France, Greece, Germany and Austria.
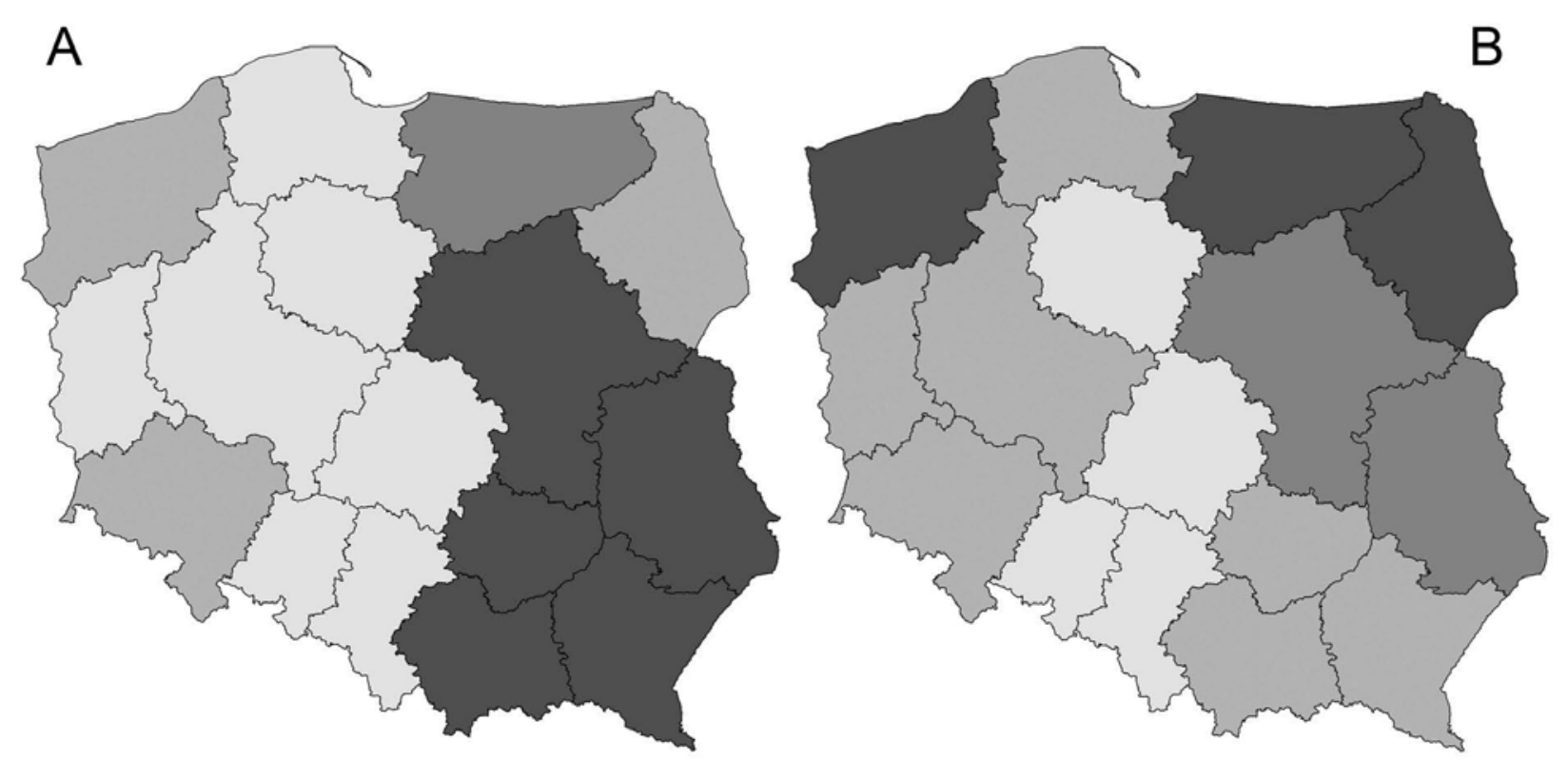

Subcarpathia and Mazovia (11\% each). In 2014, far more organic farms were found in voivodeships with very large farms, i.e. in WarmiaMazuria and West Pomerania. The greatest changes in their number occurred in western voivodeships (West Pomerania and Lubuska Land), and in northern ones (Warmia-Mazuria, West Pomerania and Podlasie) - Fig. 5.

Similarly, the increase in the number of organic farms in the years 2003-2015 was accompanied by an increase in the area of organic farmland. Until 2013 this increase was linear, as illustrated by the trend line shown in Fig. 6 .
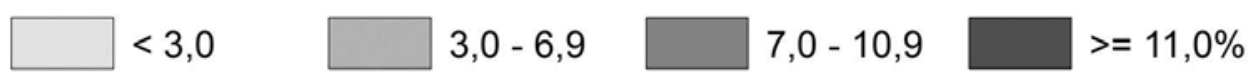

Fig. 4. Proportion of organic farms in the total number of farms in Poland by voivodeship, 2004 (A) and 2014 (B). Source: own calculations based on data from the Agricultural Census. 


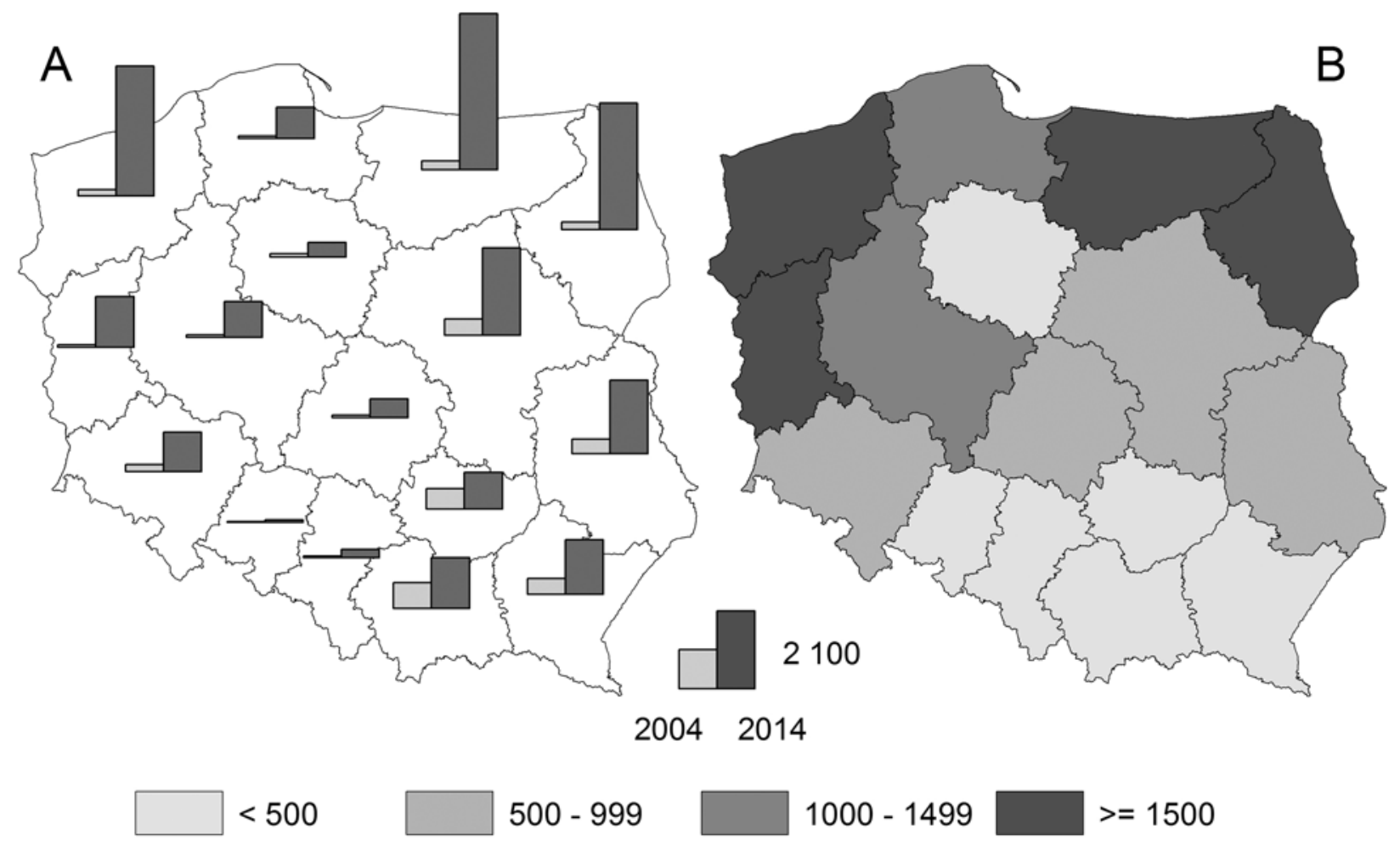

Fig. 5. Number of (A) and changes in (B) organic farms in Poland by voivodeship, 2004 and $2014(2004=100)$. Source: own calculations based on data from the Agricultural Census.

During this period, the equation of the straight line trend for ecological farmland area took the form of $y=55,430 x+13,403$. This means that the average annual increase in its area was 55,430 ha. $93 \%$ of the equation of the straight line trend is explained by a matching regression line $\left(\mathrm{R}^{2}=\right.$ 0.924).
The largest increase in the area occurred between 2009 and 2010, when it grew by 100,000 ha in relation to the previous year. Poland is second globally in terms of growth in the area devoted to organic farming (Zegar 2012). After 2014, for the first time since Poland's accession to the EU, the number of organic farms dropped to 23,015

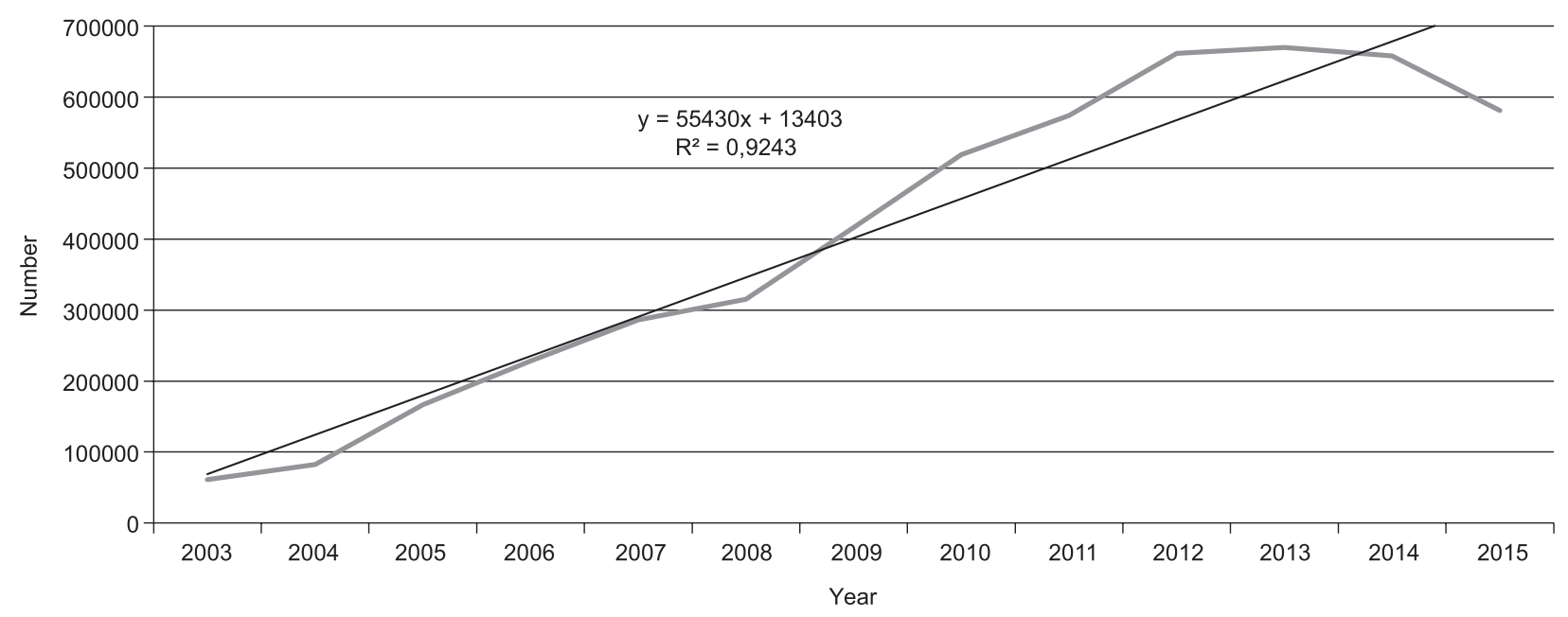

Fig. 6. Agricultural land in organic production in Poland, 2003-2015 (ha). Source: own calculations based on the IJHARS report. 
Table 2. Changes in the area of organic farmland in Poland, 2004-2015.

\begin{tabular}{|c|c|c|c|c|c|c|}
\hline Year & Number & $\begin{array}{c}\text { Growth in number } \\
\text { of organic farms } \\
\text { from previous }\end{array}$ & Area [ha] & $\begin{array}{c}\text { Growth in area of } \\
\text { organic farms from } \\
\text { previous year [ha] }\end{array}$ & $\begin{array}{c}\text { Average area } \\
\text { of organic } \\
\text { farms [ha] }\end{array}$ & $\begin{array}{c}\text { Change in average } \\
\text { area of organic farms } \\
\text { from previous year } \\
\text { [ha] }\end{array}$ \\
\hline 2003 & 2,286 & - & 61,236 & - & 26.8 & - \\
\hline 2004 & 3,760 & 1,474 & 82,730 & 21,494 & 22.0 & -4.8 \\
\hline 2005 & 7,182 & 3,422 & 166,300 & 83,570 & 23.2 & 1.2 \\
\hline 2006 & 9,187 & 2,005 & 228,009 & 61,709 & 24.8 & 1.7 \\
\hline 2007 & 11,870 & 2,683 & 285,878 & 57,869 & 24.1 & -0.7 \\
\hline 2008 & 14,896 & 3,026 & 314,921 & 29,043 & 21.1 & -2.9 \\
\hline 2009 & 17,091 & 2,195 & 416,261 & 101,340 & 24.4 & 3.2 \\
\hline 2010 & 20,582 & 3,491 & 519,068 & 102,807 & 25.2 & 0.9 \\
\hline 2011 & 23,449 & 2,867 & 573,687 & 54,619 & 24.5 & -0.8 \\
\hline 2012 & 25,944 & 2,495 & 661,687 & 88,000 & 25.5 & 1.0 \\
\hline 2013 & 26,598 & 654 & 669,963 & 8276 & 25.2 & -0.3 \\
\hline 2014 & 24,829 & $-1,769$ & 657,902 & $-12,061$ & 26.5 & 1.3 \\
\hline 2015 & 22,277 & $-2,552$ & 580,730 & $-77,172$ & 26.1 & -0.4 \\
\hline
\end{tabular}

Source: own calculations based on the IJHARS report.

in 2015. The largest decrease in the number of organic producers, relative to 2013, was recorded in Małopolska (-456), Subcarpathia (-269) and Świętokrzyska Land (-212). From 2013, a decrease in their area was recorded (Table 2).

The largest organically utilised areas in 2015 were found in the voivodeships of Pomerania (143,648.2 ha), Warmia-Mazuria (140,845.3 ha) and Podlasie (63,599.4 ha) - Fig. 7.
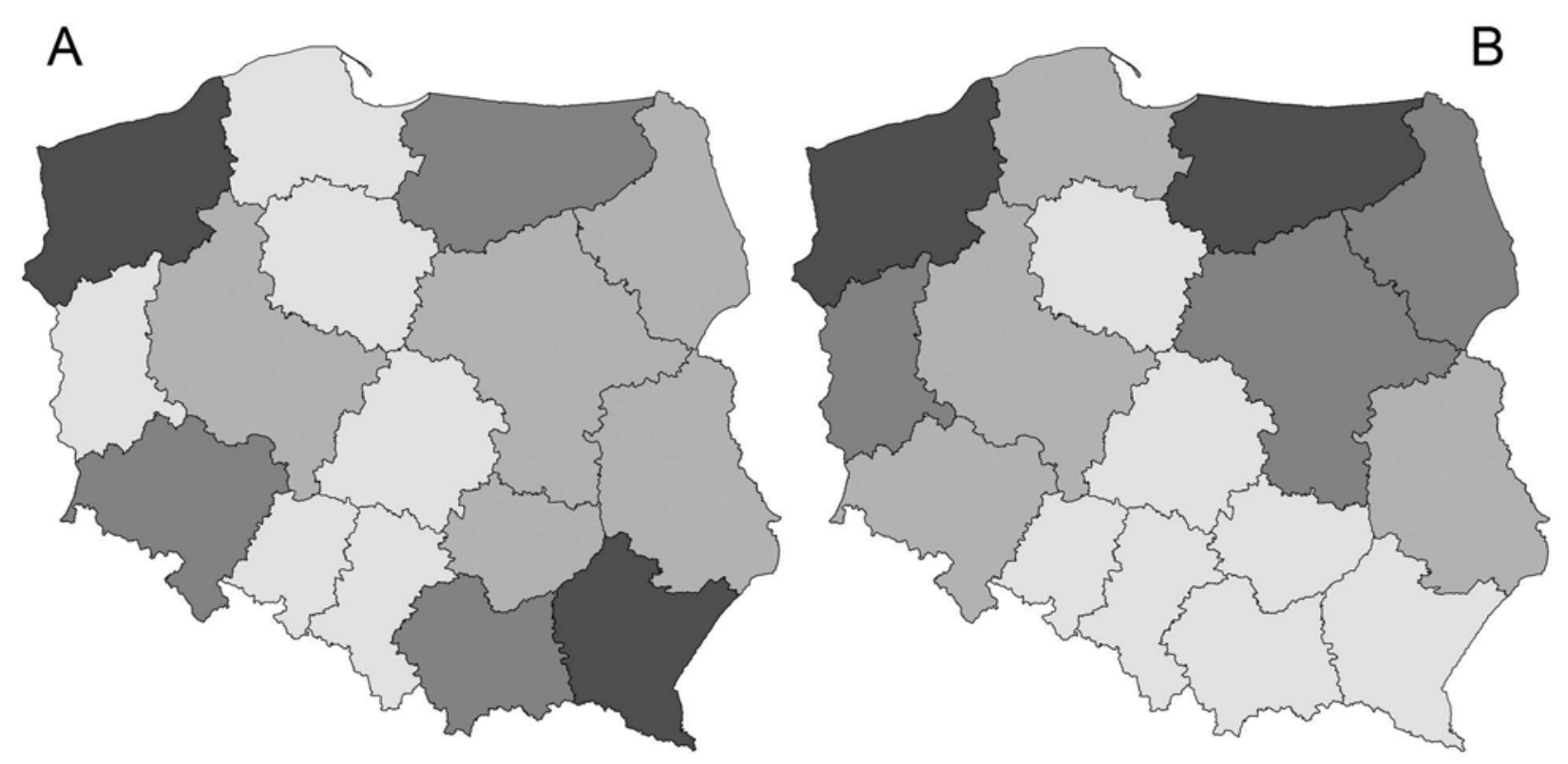

A comparative analysis of the share of ecological areas by voivodeship in the years 2004-2014 shows that in 2004 the largest were recorded in West Pomerania (15.4\%), Subcarpathia (12.9\%) and Lower Silesia (10.6\%). In 2014 their proportion was still large in West Pomerania (19.7\%), followed by Warmia-Mazuria (17.8\%), while in Subcarpathia it fell to $3.6 \%$. Changes in the area of organic farms are the greatest in Lubuska Land (Fig. 8).
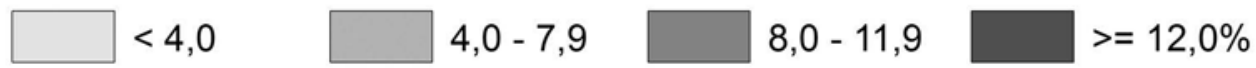

Fig. 7. Proportion of organic farms in Poland by size and voivodeship, 2004 (A) and 2014 (B). Source: own calculations based on data from the Agricultural Census. 


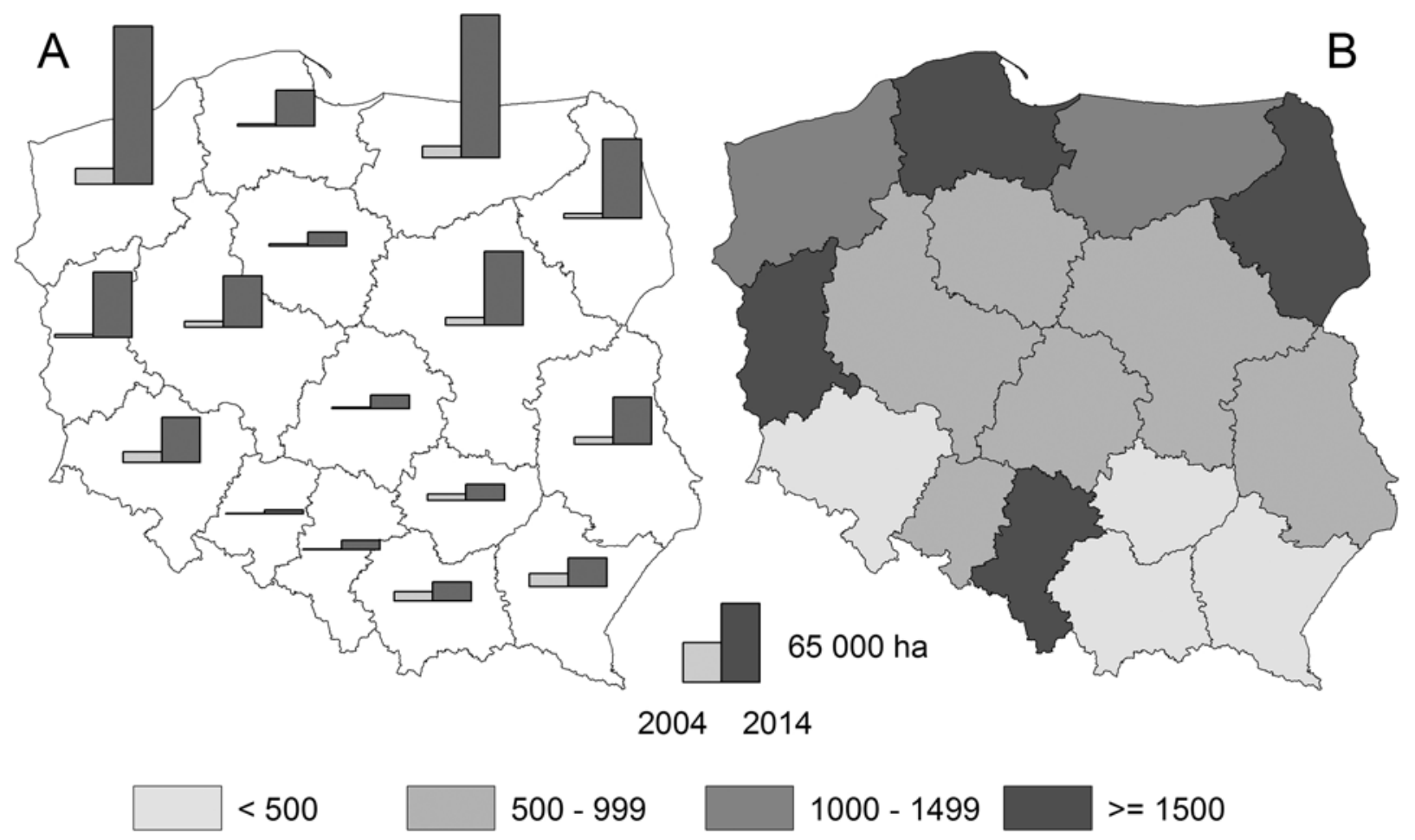

Fig. 8. Area of (A) and changes in (B) the number of organic farms in Poland by voivodeship, 2004-2014 $(2004=100)$.

Source: own calculations based on data from the Agricultural Census.

The structure of organic farms by size group in Poland in 2014 is presented in Fig. 9. Almost a half $(49.7 \%)$ of them are either in the $20-50$ ha group (25.2\%), or in the $10-20$ ha group (24.5\%).

In 2015 the average size of organic farms in Poland amounted to 26.1 ha. Compared with 2004, the average farm size had increased slightly (by 4.1 ha). In the years 2003-2014 the average size of an organic farm remained at about 25 ha, higher than the average size of conventional farms (10 ha, Jezierska-Thöle et al. 2014). At that time, the

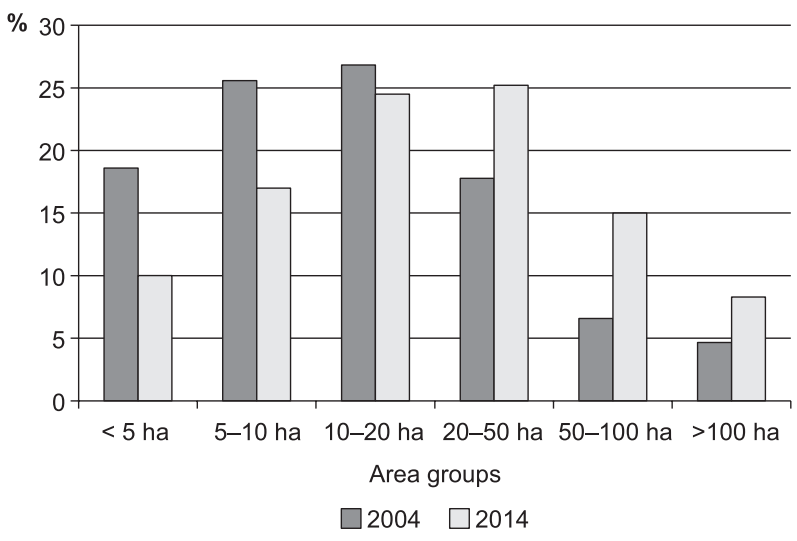

Fig. 9. Changes in the proportions of farms of over 1 ha in area, 2004 and 2014 (\%).

Source: own calculations based on the IJHARS report.

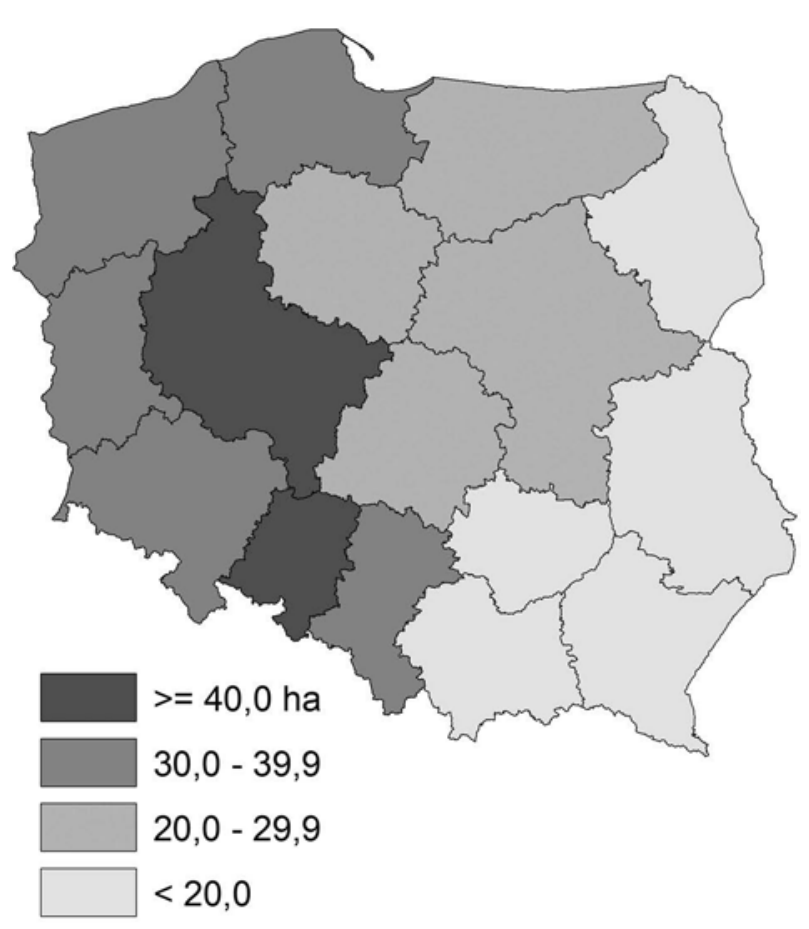

Fig. 10. Average size of organic farms in Poland by voivodeship, 2014.

Source: own calculations based on the IJHARS report. 
equation of the straight line trend of the average area of organic farmland took the form $y=0.182$, $x=23.28$. This means that the average size of organic farms increased by 0.182 ha annually. In 2014 it varied regionally and ranged between 11 and 13 ha in Małopolska and Świętokrzyska Land, respectively, to 44 ha in Opole voivodeship and Wielkopolska (Fig. 10).

A spatial analysis shows that in 2014 the greatest share of large (50-100 ha) and very large farms (> 100 ha) was recorded in Wielkopolska (29.4\%), followed by Opole voivodeship (26.7\%), Lubuska Land and Silesia (24\% each). A large share of small farms was recorded in Małopolska (40\%) as well as Świętokrzyska Land and Lublin voivodeship (20\% each). Major changes occurred in the structure of individual groups. Between 2004 and 2014, the share of farms of over 20 ha increased from $29.0 \%$ to $48.5 \%$, with the biggest increase in the group of $50-100$ ha, i.e. from $6.6 \%$ to $15.0 \%$ (Fig. 9). In 2004, most farms ranged from 5 to 20 ha, while in 2014 from 10 to 50 ha, and they accounted for $52 \%$ and $49.7 \%$, respectively, of the total number of organic farms in Poland (Fig. 11).

\section{Organic production}

The crop structure in 2014 was dominated by fodder plants (35.8\%), followed by meadows and pastures $(31.5 \%)$. A high proportion was also taken up by cereals (16.9\%). Other crops (Fig. 12) accounted for about $10 \%$ : fruits and berries $(8.9 \%)$, vegetables $(4.1 \%)$, industrial crops $(0.7 \%)$, potatoes $(0.4 \%)$, and others $(0.6 \%)$.

As to livestock production, cattle have the biggest proportion, in terms of both milk and meat, along with horses (Musiał 2008). As to milk production, the largest shares are taken by Małopolska, Subcarpathia and Warmia-Mazuria. Livestock density allows ecological potato cultivation on manure, and in those voivodeships it is the basic root crop. Horse breeding is mainly associated with agro-tourism. Sheep rearing, which could be developed in southern voivodeships, is not that popular among organic producers. This is primarily due to the small consumption of their meat by Polish consumers.

Organic producers are divided into two groups. The first consists of farmers involved
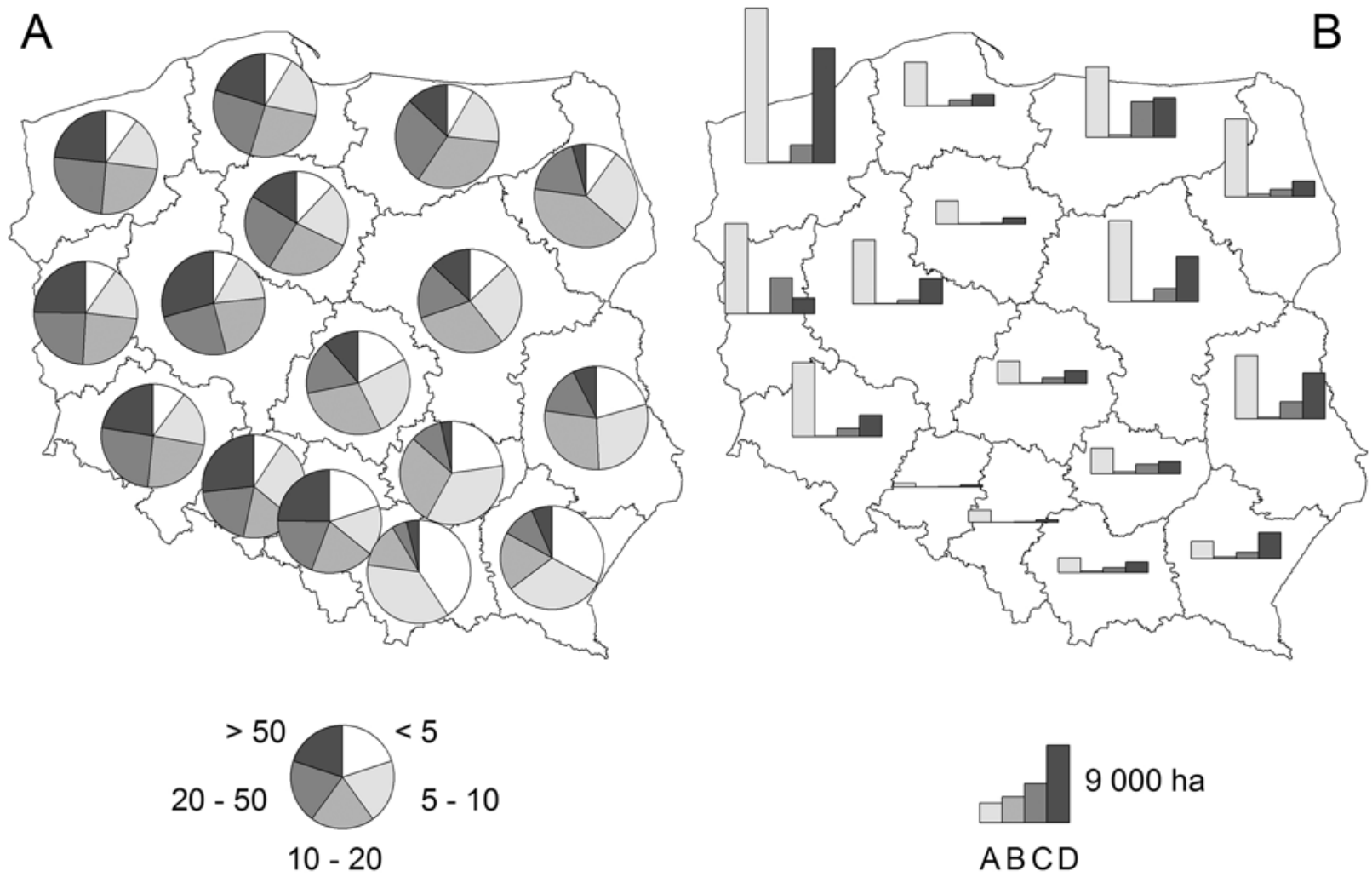

Fig. 11. Structure of organic farms by size group (A) and area of organic crops (\%) (B), 2014. A - cereals, B - potatoes, C - vegetables, D - fruit. Source: own calculations based on the IJHARS report. 


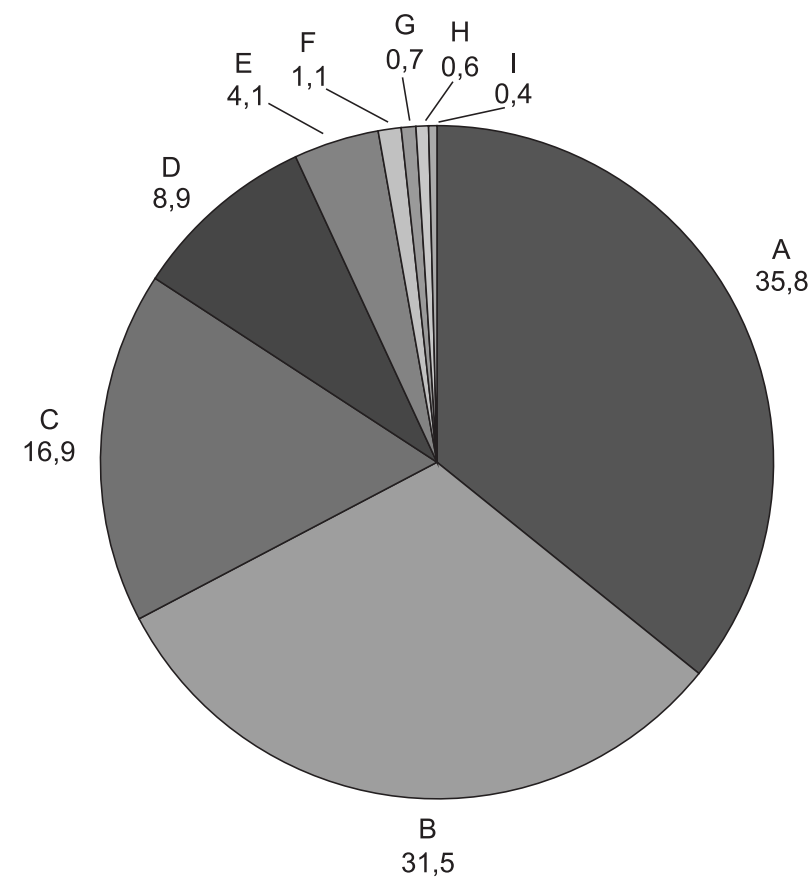

Fig. 12. Structure of organic crops in Poland, 2014 (\%).

A - fodder crops, B - meadows and pastures, C - cereals, D - orchards and fruit bushes, $\mathrm{E}$ - vegetables,

F - leguminous crops, G - industrial crops, H - other, I - potatoes.

Source: own calculations based on the IJHARS report.

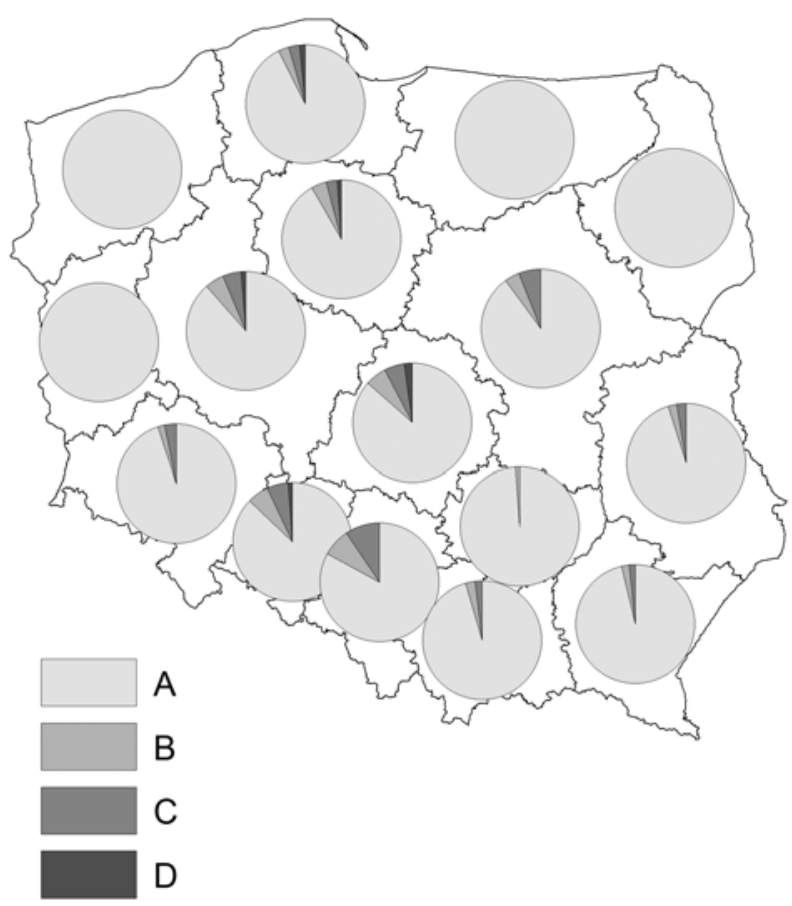

Fig. 13. Proportion of businesses involved in organic agriculture in Poland, 2014.

A - agricultural production, B - processing of organic products, C - marketing organic products, D - supplying certified seed and vegetative propagating material. Source: own calculations based on the IJHARS report. in plant and animal production, while the other includes those who process crops and livestock, and distribute the processed organic products. Fig. 13 shows the share of organic producers by business category. The largest group includes farmers representing $96.1 \%$ of the total, while those who market organic products and those who deal with the processing of organic products account just for 3.3\%. By voivodeship, Silesia $(8.0 \%)$ has the greatest share, followed by Łódź and Opole voivodeships (6.2\% each). The largest groups of producers involved in beekeeping were found in Łódź voivodeship, Subcarpathia, Kujavia-Pomerania and Pomerania $(0.6 \%$ each; Fig. 13).

\section{Case study: an organic farm in Brodnica poviat}

The survey on the development of organic farms was carried out in the summer of 2016 in Brodnica poviat; this is where the Eko-łan association operates, embracing over a hundred organic farmers and those involved in the processing of organic produce. The association evolved from the provincial branch of the EKOLAND association formed in 1990. More than half of its members come from that poviat, and $80 \%$ from Kujavia-Pomerania. In Brodnica poviat there are 50 organic farms, many of them offering agro-tourist services. Together with the adjacent poviats - Nowe Miasto and Golub - this area has about 100 organic farms. The average size of one is $20 \mathrm{ha}$, which is twice as much as the average for the poviat (12 ha). More than half of the organic farms are engaged in the production of cereals, one-quarter in livestock (cattle, laying hens), while the rest grow vegetables and fruit. There are six major plants there processing organic produce. Producers cooperate with two local fruit and vegetable cooling plants (Miesiączkowo and Grudziądz). Crops from organic farms are sold almost solely within the poviat to local processing plants, or directly to customers.

Organic farming in Brodnica poviat plays a very important role in local development. Through its activities, it follows the requirements of environmental protection and builds the awareness of producers and residents. Organic farms are a major employer in the region, especially 
during fruit and vegetable picking and the harvest, which helps to reduce unemployment in the poviat $(10 \%$ in 2016$)$. Organic production influences the development of processing industries, again employing locally. Some of the plants are model institutions, visited by children and adolescents seeking environmental education (about 3,000 visitors per year) while they also conduct direct sales. According to Mieczysław Babalski (interviewed in 2016), organic farming supports the profitability of small and medium-sized farms, and indirectly helps reduce rural depopulation.

The organic farm of Mieczysław Babalski is certified by the National Association of Organic Food Producers EKOLAND. The farm is located in Pokrzydowo, Zbiczno commune (Brodnica poviat) in the south-eastern part of Kujavia-Pomerania in the Brodnica Lake District. Organic agricultural land is located in the Brodnica Landscape Park, which is part of the 'Green Lungs of Poland'; this makes the farm even more attractive in terms of organic production. Ecological activities on the farm have been conducted since 1991; it has an area of 9 ha, including 1.10 ha of orchards (apple and plum trees). Arable land of classes III to VI is used for growing cereals (old cereal types, like spelt, emmer and einkorn wheat). The farm runs an old apple-tree nursery. Livestock consists of red cattle (five heads) and poultry (150 green-legged partridge hens). Apart from plant and animal production, Babalski runs organic cereal processing. His production includes whole-wheat flour, whole-wheat pasta, cereals, bran, groats, spelt coffee, as well as pillows and mattresses from buckwheat and spelt chaff.

According to Babalski, there are a lot of factors limiting the development of trade in organic products, including the absence of adequate legal enforcement mechanisms that protect the names of organic products. Many products on the market, e.g. made of soy, identified as 'healthy foods' are actually produced with the use of chemicals and genetic manipulation. A major difficulty is that organic farms are scattered across the country and there is no proper organisation of the market, especially of vegetables, fruit, milk and meat. The best organic food trade operates in the voivodeships which have most processing plants, i.e. in Kujavia-Pomerania, Mazovia and Łódź, and around major cities. So far, the best form of trade in organic products is direct sales, practised in Łódź and Warsaw. The opportunity for selling organic products (strawberries, blackcurrants, apples, tomatoes, onions, carrots, cauliflowers) lies in the EU market. Currently, only 10-15\% of the domestic organic production goes to EU countries, despite the fact that interest in organic products from Poland is very high. The barrier is the scale of production. Therefore, organic farmers should unite and form producer groups or cooperate informally. Currently, Polish products have their largest markets in Germany, the UK and Scandinavia.

\section{Summing up}

Organic farming as a new form of agricultural production had already appeared in the 1930s. However, its dynamic development is taking place today and results from a new approach to rural development. The current paradigm of development is sustainability. Organic farming is part of a sustainable development model, at the same time becoming a prerequisite for multifunctional development in rural areas. The study showed that in the years 2003-2015 Poland saw a rapid increase in the number and area of organic farms due, in part, to the introduction of $\mathrm{EU}$ subsidies as well as EU legal regulations on organic farming. A spatial analysis of the share of the number of farms by voivodeship shows that in 2015 most farms were recorded in WarmiaMazuria (4,041), Podlasie $(3,273)$ and West Pomerania $(3,043)$. In parallel to the increase in the number of organic farms, the years 2003-2015 saw an increase in the area of organic farmland, the largest occurring in 2009 and 2010 when in relation to the previous year it had expanded by 100,000 ha.

Poland is second in the world in terms of growth in the area of organic farms. In 2015 the largest areas were recorded in Pomerania (143,648.2 ha), Warmia-Mazuria (140,845.3 ha) and Podlasie (63,599.4 ha). At that time, the average size of organic farms in Poland amounted to 26.1 ha. In the years 2003-2014 it remained about 25 ha and was higher than of a conventional farm (10 ha). In the analysed period, the share of farms of over 20 ha increased from $29.0 \%$ to $48.5 \%$, with the biggest rise recorded in the range of 50-100 ha: from $6.6 \%$ to $15.0 \%$. In 2014 the crop structure 
was dominated by fodder plants $(35.8 \%)$, followed by meadows and pastures $(31.5 \%)$. The proportion of cereals was also high (16.9\%). In terms of livestock production, cattle and horses were the most important animals.

As the results of a field research show, an increasing number of farmers have decided to convert their farms to organic production. For many farmers, this is a chance to earn an income through the sale of healthy and ecological food, as well as an opportunity to apply for a subsidy per hectare of organic production under the RDP 2007-2013.

The popularity of organic farming in Poland is supported by the following elements: a dominance of small and medium-sized family farms, large resources and relatively low labour costs, a relatively low level of consumption of chemicals, introduction of subsidies from national and EU budgets, as well as the price competitiveness of Polish organic products on EU markets. Thanks to EU subsidies, more and more farms in Poland have switched to organic production. It can be assumed that over the next few years the share of organic agricultural area will exceed $4-5 \%$. On the common EU market Polish organic farms can become more competitive in labour-intensive organic production. Polish organic farming, with its small family farms employing local people for seasonal fieldwork, is a great opportunity. In addition to the important ecological function they also perform social ones.

The results of the field research confirm that the development of organic farms in Poland is hampered by a weak network of organic product distribution, fragmented supply and demand, as well as low levels of marketing and the short shelf life of products for human consumption. That is why it seems important to increase the involvement of local governments in the development of organic farming and the ecological education of society.

\section{References}

Christian H., 2008. Determinants of agricultural protection in an international perspective: the role of political institutions. 12 $2^{\text {th }}$ European Congress of Agricultural Economists, Gandawa.

Granstedt A., Tyburski J., 2006. Współczesne europejskie systemy rolnicze (Modern European agricultural systems). Fragmenta Agronomica 2: 72-95.
Grykień S., 2005. Bariery rozwoju rolnictwa ekologicznego w Polsce (Barriers to the development of organic farming in Poland). In: Pałka E. (ed.), Funkcje obszarów wiejskich. Wyd. Akademii Świętokrzyskiej, Kielce.

Hamm U., Gronefeld F., 2004. The European market for organic food. Revised and updated analysis. School of Management and Business, University of Wales, Aberystwyth.

Hirschfeld J., Wessi J., Kornbun T., 2009. Ansiäte einer Klima reundlichen Agroarpolityk. Ökologisch Wirtschafen 1: 15-16.

Jezierska-Thöle A., Biczkowski M., 2013. Znaczenie i uwarunkowania innowacyjności $\mathrm{w}$ rolnictwie $\mathrm{w}$ Polsce (Importance and determinants of innovation in agriculture in Poland). Roczniki Naukowe Stowarzyszenia Ekonomistów Rolnictwa i Agrobiznesu 15 (2): 124-131.

Jezierska-Thöle A., Janzen J., Rudnicki R., 2014. Agrarian-economic structure of agricultural holdings in Poland and East Germany: Selected elements of comparative analysis. Questiones Geographicae 33(2): 87-101.

Jezierska-Thöle A., Rudnicki R., Kluba M., 2016. Development of energy crops cultivation for biomass production in Poland. Renewable and Sustainable Energy Reviews 62: 534-545.

Koepf H., Plato B., 2001. Die biologisch-dynamische Wirtschaftsweise im 20. Jahrhundert. Die Entwicklungsgeschichte der biologisch-dynamischen Landwirtschaft. Verlag am Goetheanun. Dornach/Schweiz.

Kołodziejczak A., 2015. Wielofunkcyjność rolnictwa jako czynnik rozwoju zrównoważonego obszarów wiejskich w Polsce (Multifunctionality of agriculture as a sustainable development factor of rural areas in Poland). Studia Obszarów Wiejskich 37: 131-142.

Kozłowska 1999. Rolnictwo ekologiczne - czy ma szansę na rozwój? (Organic farming - has it got a chance for development?). Rolnictwo 5: 472.

Kuś J., 2002. Systemy gospodarowania w rolnictwie (Systems of management in agriculture). In: Mały poradnik zarzadzania gospodarstwem rolniczym. Mat. szkol. 9, IERiGŻ: 119-126.

Łuczka-Bakuła W., 1997. Ekologizacja rolnictwa a zmiany w świadomości i postawach rolników (Greening of agriculture and changes in the awareness and attitudes of farmers) In: Problemy dydaktyki $i$ wychowania w Akademii Rolniczej w Poznaniu. Wyd. Akademii Rolniczej im. Augusta Cieszkowskiego w Poznaniu.

Musiał W., 2008. Ekonomiczne $i$ społeczne problemy rozwoju obszarów wiejskich Karpat Polskich (Economic and social problems of rural development in the Polish Carpathians). IRWiR - PAN, Warszawa.

Pearce D., Turner K.R., 1990. Economics of Natural Resources and the Environment. New York. 35-42.

Pradziadowicz M., 2013. Funkcjonowanie gospodarstw ekologicznych w Pomorzu Zachodnim w latach 2006-2011 (Functioning of organic farms in West Pomerania in the years 2006-2011). J. Agribus. Rural Dev. 2(28): 205-213.

Rogall H., 2010. Ekonomia zrównoważonego rozwoju. Teoria $i$ praktyka (Economics of sustainable development. Theory and practice). Zysk i S-ka, Poznań.

Runowski H., 2009. Rolnictwo ekologiczne - rozwój czy regres? (Organic farming - development or regression?) Roczn. Nauk. SERiA 96 (4): 182-193.

Sołtysiak U., 1993. Rolnictwo ekologiczne - historyczny przegląd metod (Organic farming - a historical overview of methods). In: Rolnictwo ekologiczne od teorii do prakty- 
ki, Stowarzyszenie EKOLAND, Stiftung LEBEN \& UMWELT, Warszawa.

Stachowicz T. (ed.), 2008. Prowadzenie gospodarstw ekologicznych (Running organic farms). Radom.

Stankiewicz D., 2001. Rolnictwo ekologiczne (Organic farming). Wyd Sejmowe dla Biura Analiz Sejmowych 2009, 7(54): $1-4$.

Stawicka J., Szymczak-Piątek M., Wieczorek J., 2004. Wybrane zagadnienia ekologiczne (Selected ecological issues). Wyd. SGGW.

Tabo S., Szczuka M., 2012. Charakterystyka wyposażenia technicznego i technologii uprawy roli $\mathrm{w}$ gospodarstwach ekologicznych (Characteristics of technical equipment and cultivation technology on organic farms). Agricultural Engineering 2(137): 295-302.

World of Organic Agriculture. Statistics and Emerging Trends, 2010. FiBLIN FOAM.

Vogt G., 2000. Entstehung und Entwicklung des ökologischen Landbaus. Ökologische Konzepte, SÖL, Bad Dürkheim.

Zegar J.S., 2012. Wspótczesne wyzwanie w rolnictwie (Modern challenge in agriculture). PWN, Warszawa.

Zysnarska E., 1997. Ekonomiczne uwarunkowania rozwoju produkcji żywności wytwarzanej metodami ekologicznymi w Polsce (Economic determinants of the development of the production of food produced organically in Poland). UMK, Torun. 